\title{
Inter-Provincial Spatial Linkages of Crime Pattern in Indonesia: Looking at Education and Economic Inequality Effects on Crime
}

\author{
Dian Trisnawati ${ }^{1}$, Khoirunurrofik ${ }^{1,2,}$ and Deny Syamsurya Ismail ${ }^{2}$ \\ ${ }^{1}$ Master Program of Economic Planning and Public Policy, Faculty of Economics and Business, Universitas Indonesia \\ ${ }^{2}$ Urban Development Studies, School of Strategic and Global Studies, Universitas Indonesia
}

Received: 2018-06-06 Accepted: 2019-07-16

Keywords:

Crime rate;

Gini index;

school dropout;

panel data;

patial autocorrelation.

Corespondent Email:

khoirunurrofik@ui.ac.id

\begin{abstract}
Crime is one of social issues and it becomes spatial phenomenon as the inclination of crime rate in a particular region affecting its neighboring regions. This paper aims to explore the inter-provincial spatial linkages of crime rate in Indonesia and examine the effects of lack of education and economic inequality on criminal occurrences. Panel data of 33 provinces in Indonesia from 2007-2013 periods are explored and discover the existence of spatial linkages of crime rate among provinces. The spatial autocorrelation (SAC) model shows that the economic gap amid the society become the trigger for crime occurrence. Criminal actions are expected to increase as the Gini index is high since the inequality can make social jealousy is inevitable and triggering criminal actions. Furthermore, lack of education is also proven significantly in affecting crime rate, imply that education level may affect individual's decision to commit criminal actions.
\end{abstract}

This article is an open access article distributed under the terms and conditions of the Creative Commons

Attribution(CC BY NC) licensehttps://creativecommons.org/licenses/by-nc/4.0

\section{Introduction}

Economics perceives crime as a phenomenon requiring immediate eradication due to the high cost for its impacts. The cost borne by the victims of crime include property loss, medical cost in case trauma is incurred, pain, suffer, loss of opportunity cost in the form of working hours, and decreasing value of life. In addition, the necessary cost for trial process, such as police, court, the necessary cost for facilities recovery, and preventive cost become the financial burden for the crime victims (Sullivan ,2012). According to Indonesia Police Watch, Indonesia's crime rate is classified as relatively high incident, it can be observed from several cases that remain unsolved by the Police of Republic of Indonesia (Republika,2014). To explain crime occurrence, it becomes paramount to utilize spatial analysis since the combination of location illustration and crime occurrence will not only assist to comprehend locations requiring more intervention for crime management, but also to determine the primary location as the target for crime management (Anselin, et al. 2000). The rate of crime in one particular region may be affected by the geographical conditions of other regions since the relation between crime rate and the crime location is deemed as one of spatial data phenomena, as Tobler (1979) has explained in his law of geography, that everything is interconnected, but something closer inflicts more influence than something in distant.

Referring to Indonesia Central Statistics Bureau, the measurement of society's sense of security can be approached using negative indicator, such as number of potential crime offenders (crime rate). Crime rate is defined as the number of crime victims per 100.000 of population. It indicates the exposure to the risk of criminal actions at any given time. The rate of crime in big cities performs higher index in comparison to the small cities or rural areas. Urban areas become a lucrative target of crime due to the higher return of crime, low probability of being arrested, low confession probability, and the other attractiveness of cities itself (Glaeser and Sacerdote, 1996).

Moreover, Sharp, et al. (2012) revealed that there are unlimited motives for committing crime; yet, economic motive is the main trigger. This finding supports the theory from Becker (1968) that an individual will commit crime/illegal actions if the expected utility earned from the amount of time and resources used to illegal actions outweigh the expected utility earned from legal actions. People commit to crime may not because of different initial motives among them, but because of different cost and benefit analysis. More recent, Sullivan (2012) argued that committing crime is perceived as a rational decision according to economic approach because of its purpose for utility maximization. The decision to opt for either legal or illegal actions is decided from activities providing maximum utility.

Related to education level, Moretti (2005) mentioned that the effects of education towards crime rate are reflected implicitly from uncountable benefits 
of schooling; therefore, actually, social returns of schooling outnumber the private returns of schooling. Before that, Lochner (2004) has stressed the importance education as human capital investment to prepare for more prosperous future through legal job opportunity in order to prevent people committing criminal actions. If human capital investment increases the marginal return of work, which is greater than marginal return of committing crime, human capital investment and schooling will be able to decrease crime occurrence. Furthermore, Entorf and Sieger (2015) found that an unemployed will show a different behavior in his decision to commit a crime that is associated, either he lives in high or low crime environment. So that, someone who has a longer time as unemployed and teenagers drop out of school, may have great potential to commit a crime as they may be involved in any live environments.

Meanwhile, the relation between crime rate and unemployment rate was firstly examined by Becker (1968) who formulized about the tightening labor market (decrease the opportunity to earn income from legal sources leading to increasing crime occurrence). The narrowing opportunity to have access to earn legal income is one of paramount factors inducing criminal actions. The adequate legal income should have been able to decrease crime rate since it represents the opportunity cost of being arrested. Furthermore, Bharadwaj (2014) study revealed that poverty, income inequality, and subdued law enforcement are positively correlated with property crime. Poverty becomes the primary factors inducing people to rob. According to relative deprivation theory, individual may commit criminal actions to convey a signal to the nation that the system in place where they reside is not compatible with their condition and their position in the community. So that, A person's choice in committing a crime through the calculation of losses and benefits, is based on economic conditions that allow illegal income to be greater than legal income (Engelen et.al.,2016). In the context of Indonesia, it is proven that poverty, economic inequality is among factors that positively associated with communal conflict in Indonesia (Sujarwoto, 2017), which the conflict itself can be part of criminal violence.

In accordance with Becker's statement (1968), one of factors affecting the expected degree of utility in committing crime include the probability of being convicted, the bigger the probability of it, the lower the expected utility from doing crime. The increasing number of police officers, which negatively affects crime rate, will decrease the probability of crime occurrence by magnifying the probability of being arrested or even convicted. Police are the first line of defense against crime. 14 percent incremental of police officers per population may decrease 5-6 percent of crime rate (Levitt, 2004). It because police is on duty to arrest anyone suspected for doing crime; hence, lowering the crime rate. Therefore, the increasing budget for police department should be able to improve the capacity of police force leading to better performance to arrest crime offenders (Becsi, 1999). Finally, we found that Bharadwaj (2014) also discovered that income disparity and crime rate are positively correlated. It because the number of poor population struggling to escape from poverty and climbing to be rich, are increasing; therefore, reducing the opportunity cost of doing crime. In other words, they feel more challenged to involve in criminal actions.

The inclination of adjacent regions to possess similar crime rate raises the question of whether the crime rate of a region is associated with its neighboring regions. Based on the aforementioned issues, this paper aims to explore the inter-provincial spatial linkages of crime rate in Indonesia and examine the effects of lack of education and economic inequality on criminal occurrences. Besides that, other important control variables such as unemployment, poverty, and number of police are also examined. The paper was estimated using spatial panel regression as suggested by Beloteli, et al (2013) and Elhost (2014). The estimation though this method is to deal with any biased due to endogenous spatial interaction among regions. Similar approach has been conducted by Sujarwoto (2017) to examine geographical determinants of communal conflicts in Indonesia using Spatial linear regression. The paper contributes to the examinations of the effects of spatial economic inequality and education level on crime rate. In the context of developing countries and particularly in Indonesia, this paper may be the first to study geographic scopes beyond single, local provinces crime rate level. It shows the presence of regional externalities and identifies that triggering factors of crime rates flowing beyond a single province.

The paper has been organized in the following way. The first section gives a brief overview of the importance of this research and a literature survey of related studies. The second section provides the empirical methods including data information and variable definition. The analyses and results are described in the fourth section. Our conclusions are drawn in the final section.

\section{The Methods}

This paper applied two regression analysis comprising classical panel regression (Ordinary Least Square) and spatial panel regression, using the 20072013 data. It utilized the cross-section data covers 33 provinces in Indonesia for 2007-2013 periods. This period is taken to cover the 2008 global financial crisis that may affect to the Indonesian economic stability as it is examined by our economic variable in this study. We apply spatial panel regression using xsmle command Beloteli, et al (2013) that require strongly balanced data (Barret,2014). Following Elhorst (2014) who mentioned that endogenous interaction effect and error interaction effect as spatial autocorrelation model (SAC), we specify a panel regression model of crime 
rate in Indonesia. The formula is adopted from (Elhorst, 2014):

$\begin{array}{lrl}\text { In Crimerate }: & \beta_{0}+ & \beta_{1} \text { GINI }+\beta_{2} D O+\beta_{3} \text { UNEM }+ \\ & \beta_{4} P O V+\beta_{5} E X P+\beta_{6} \text { Lagpolice }+ \\ & \text { BudgetPolice }+\varepsilon\end{array}$

To ensure the inter-provincial spatial linkages of crime rate, we apply Moran's Index to measure spatial autocorrelation. Moran's I global index is formulized:$$
I=\frac{N \sum_{i}^{N} \sum_{j}^{N} W_{i j}\left(Y_{i}-\bar{Y}\right)\left(Y_{j}-\bar{Y}\right)}{\sum_{i}^{N} \sum_{j}^{N} W_{i j} \sum_{i}^{N}\left(Y_{i}-\bar{Y}\right)^{2}}
$$

In which is the average observation in the whole regional coverage and is the spatial weights between region $i$ and region $j$. Moran's I global index ranging from $-1<\mathrm{I}<1$. Positive value of I indicates the existence of agglomeration of regions possessing similar characteristics, while negative value of I indicates he existence of agglomeration of regions possessing disparate characteristics. If the value of I is almost zero, showing that the inter-regional linkages does not exist

Furthermore, in spatial data analysis, spatial linkage is called as neighborhood relationship and that is important and may affect to the estimation results.
Bustaman et al. (2014) mentioned that in spatial data analysis, regional linkages is commonly named as relationship of adjacency. The neighborhood criterion can be observed from two sides, comprising contiguity and distance. Vidyattama (2012) argued that usage of contiguity as neighborhood criteria in Indonesia context may not be visible, considering that some provinces may not have any neighbor because of being bordered by sea. Thus, this research utilizes distance as neighborhood criteria.

Bustaman et al. (2014) stated that neighborhood criteria is referred as a base of spatial weights matrix formation. The elements of spatial weights matrix is conceived:

$\left|\begin{array}{cccc}w_{11} & w_{N 1} & \ldots & w_{1 N} \\ w_{21} & w_{22} & \ldots & w_{2 N} \\ \vdots & \vdots & \ddots & \vdots \\ w_{N 1} & w_{N 2} & \ldots & w_{N N}\end{array}\right|$

Row and column in spatial weights matrix indicate regions of analysis unit. Wij is the regional linkage weights from region $i$ to region $j$, in which wij $\geq 0$, wij $=$ wji and wii $=0$ for $\mathrm{i}=1,2,3, \ldots \ldots, \mathrm{N}$. To omit the dependency towards data scale, standardization of spatial weights matrix elements is required.

\section{Result and Discussion}

The Figure 1 depicts visual illustration of crime rate distribution plotted in thematic map. From the map, it can be observed that the crime rate of the adjacent regions tends to fall in the same range. It also applies for property crime cases. The average crime rate in Indonesia in 2007-2013 is 1,164, with the lowest average is 606 in Central Kalimantan and the highest average is 1,950 in West Nusa Tenggara.

Table 1. Variables, Operational Definition of Variables, and Sources of Data

\begin{tabular}{|c|c|c|}
\hline Variables & Operational Definition & Sources of Data \\
\hline $\begin{array}{l}\text { Dependent Variables } \\
\text { Crime rate (Crimerate) }\end{array}$ & $\begin{array}{l}\text { Number of crime victim per } 100.000 \text { of } \\
\text { population }\end{array}$ & $\begin{array}{l}\text { Statistics of crime in National } \\
\text { Socio-Economic Survey (BPS) }\end{array}$ \\
\hline $\begin{array}{l}\text { Independent Variables } \\
\text { Gini index (GINI) }\end{array}$ & $\begin{array}{l}\text { Coefficient used to measure the degree of } \\
\text { income distribution inequality of population }\end{array}$ & Central Statistics Bureau (B \\
\hline $\begin{array}{l}\text { Percentage of senior high school } \\
\text { dropout (DO) }\end{array}$ & $\begin{array}{l}\text { The percentage of unemployed population } \\
\text { towards number of workforce population }\end{array}$ & Central Statistics Bureau (BPS) \\
\hline Poverty rate (POV) & $\begin{array}{l}\text { Percentage of population whose income falls } \\
\text { beneath the poverty line }\end{array}$ & Central Statistics Bureau (BPS) \\
\hline Total Expenditure (EXP) & $\begin{array}{l}\text { The amount of household expenditure for } \\
\text { both food and non-food expenditure }\end{array}$ & Central Statistics Bureau (BP \\
\hline $\begin{array}{l}\text { Percentage of active police officers } \\
\text { in previous year*(Police) }\end{array}$ & $\begin{array}{l}\text { Number of police in charge in each regional } \\
\text { police department divided by number of } \\
\text { population of the region }\end{array}$ & $\begin{array}{l}\text { Indonesia Police Department } \\
\text { (Mabes POLRI) }\end{array}$ \\
\hline \multicolumn{3}{|c|}{$\begin{array}{l}\text { *The data obtained from Indonesia Police Department is provincial-based police department data. Several } \\
\text { region's data of other provinces, including Banten (Tangerang, Tangerang District, and South Tangerang) } \\
\text { and West Java (Depok and Bekasi), are obtained from Polda Metro Jaya (DKI Jakarta's police department); } \\
\text { therefore, those data are disintegrated into proportion based on number of population. The latter is also ap- } \\
\text { plied for the data from South Sulawesi's police department (the compound between South Sulawesi and West } \\
\text { Sulawesi), and the data from Papua's police department (the compound between Papua and West Papua). }\end{array}$} \\
\hline
\end{tabular}




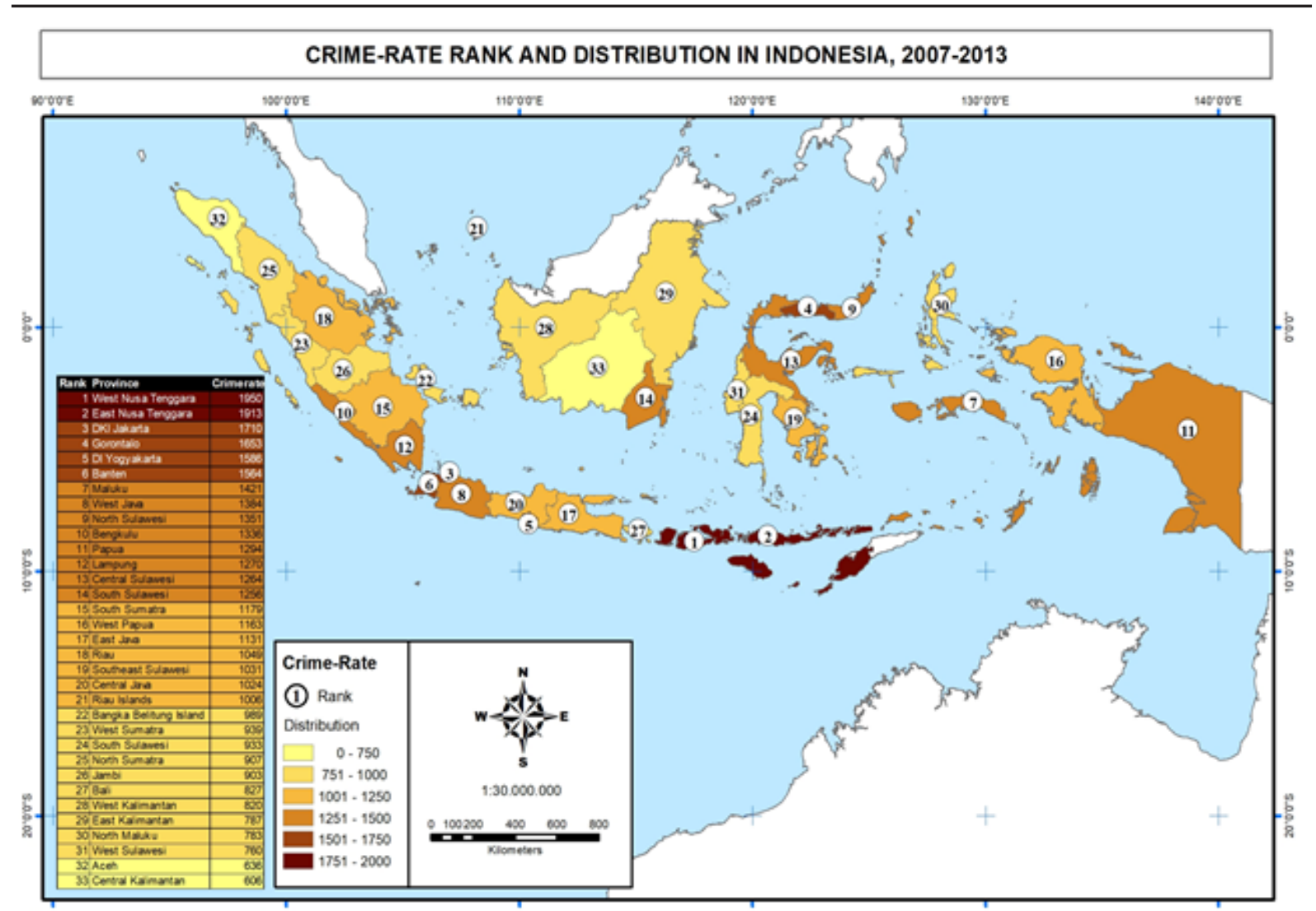

Figure 1. Crime Rate Distribution Map in Indonesia in 2007-2013

Source: Statistics of Crime, composed by authors

Table 2. Moran's Index Calculations

\begin{tabular}{lll}
\hline Variables & Index & P-Value \\
\hline lnCrimerate & 0.017 & $0.000^{\star * *}$ \\
GINI & 0.041 & $0.000^{\star * *}$ \\
DO & 0.029 & $0.000^{\star * *}$ \\
UNEM & 0.099 & $0.000^{\star * *}$ \\
POV & 0.057 & $0.000^{\star * *}$ \\
EXP & -0.001 & 0.280 \\
LagPolice & 0.193 & $0.000^{\star * *}$ \\
Note $: \mathrm{p}<0.10^{* *} \mathrm{p}<0.05^{* * *} \mathrm{p}<0.01$ &
\end{tabular}

Global Moran's Index was calculated prior to conducting spatial regression in order to examine the existence of spatial autocorrelation. The value of Moran's index is ranging from -1 and 1 for both dependent and independent variables. The obtained value indicates that all variables are statistically significant except for household expenditure and allow us to apply spatial analysis using spatial autoregression (SAR), spatial error model (SEM), spatial durbin model (SDM), and spatial autocorrelation (SAC).

These spatial econometrics approach consider that spatial autocorrelation in our dependent and independent variables exist and caused related values as provinces are closer to each other. If it does prove according to Moran's index that provinces are not independence, the estimation of the $\beta$ coefficients of standard ordinary least squared regression will give an biased estimation coefficient. The SAR model assumes that spatial linkages between the dependent variables among provinces are exist while the SEM model assumes that the errors are dependence. Furthermore, SDM Model emphasizes that spatial linkages not only in the dependent variable but also in the independent variables while SAC model just consider that the only spatial linkages between independent variables (Elhorst, 2014).

Then, the log-likehood and R2 value between the aforementioned models were compared to acquire the most compatible model. Based on the spatial regression results, the one possessing the highest value of log-likelihood is selected as the best model (see table 3). Therefore, the best spatial model is spatial autocorrelation (SAC) that indicates that the variable of crime rate and its error model can be explained using spatial approach (spillover). The results of spatial autocorrelation regression (SAC) showed that Gini index, percentage of senior high school dropout, and open unemployment rate are proven statistically significant in affecting crime spatially. Observing the coefficient of independent variables, the value of coefficient in fixed was greater than the value of coefficient in spatial autocorrelation regression (SAC). It indicates that spatial autocorrelation regression corrects overestimation in panel regression.

Spatial autocorrelation regression results indicate that crime rate imposes both direct and indirect spillover. This study provides a strong evidence that the 
Table 3. The Estimation Results of Panel Regression and Spatial Panel Regression

\begin{tabular}{|c|c|c|c|c|c|c|}
\hline Variables & $(1)$ & (3) & $(4)$ & $(5)$ & (6) & $(7)$ \\
\hline & OLS & $\mathrm{FE}$ & SAR & SEM & SDM & SAC \\
\hline \multirow[t]{2}{*}{ GINI } & $3.1265^{\star * *}$ & $3.1723^{* * *}$ & $2.2600^{\star * *}$ & $2.2543^{* * *}$ & $2.3148^{\star * *}$ & $1.7560^{* * *}$ \\
\hline & $(0.6014)$ & $(0.7982)$ & $(0.7663)$ & $(0.7627)$ & $(0.7681)$ & $(0.6449)$ \\
\hline \multirow[t]{2}{*}{ DO } & $2.2139^{\star * *}$ & $1.5827^{\star * *}$ & $0.9709^{* *}$ & $0.9580^{\star *}$ & $0.9582^{\star *}$ & $0.8646^{\star *}$ \\
\hline & $(0.5936)$ & $(0.4480)$ & $(0.4282)$ & $(0.4265)$ & $(0.4262)$ & $(0.3481)$ \\
\hline \multirow[t]{2}{*}{ UNEM } & $0.0344^{* * *}$ & $0.0451^{* *}$ & 0.0260 & 0.0241 & 0.0254 & $0.0261^{\star}$ \\
\hline & $(0.0078)$ & $(0.0186)$ & $(0.0173)$ & $(0.0174)$ & $(0.0173)$ & $(0.0141)$ \\
\hline \multirow[t]{2}{*}{ POV } & $0.0138^{\star * *}$ & $0.0291^{\star * *}$ & 0.0107 & 0.0088 & 0.0159 & 0.0145 \\
\hline & $(0.0037)$ & $(0.0106)$ & $(0.0138)$ & $(0.0139)$ & $(0.0147)$ & $(0.0112)$ \\
\hline \multirow[t]{2}{*}{ EXP } & $-0.0003^{*}$ & $-0.0004^{*}$ & 0.0000 & 0.0001 & -0.0002 & -0.0001 \\
\hline & $(0.0001)$ & $(0.0002)$ & $(0.0003)$ & $(0.0003)$ & $(0.0003)$ & $(0.0003)$ \\
\hline \multirow[t]{2}{*}{ LagPolice } & $-0.8898^{\star * *}$ & 0.6862 & 0.2888 & 0.3488 & -0.5859 & -0.1412 \\
\hline & $(0.2373)$ & $(1.0600)$ & (1.0758) & $(1.1154)$ & $(1.3901)$ & $(0.7555)$ \\
\hline \multirow[t]{2}{*}{ _cons } & $5.7073^{* * *}$ & $5.0898^{* * *}$ & & & & \\
\hline & $(0.2090)$ & $(0.4296)$ & & & & \\
\hline \multicolumn{7}{|l|}{ Spatial } \\
\hline \multirow[t]{2}{*}{ Rho } & & & 0.1002 & & 0.1148 & $0.5916^{* * *}$ \\
\hline & & & $(0.0683)$ & & $(0.0701)$ & $(0.0738)$ \\
\hline \multirow[t]{2}{*}{ Lambda } & & & & 0.1063 & & $-0.5884^{\star * *}$ \\
\hline & & & & $(0.0725)$ & & $(0.0919)$ \\
\hline $\mathrm{Ll}$ & -56.6223 & 64.8160 & 78.5599 & 78.5608 & 82.1881 & 83.6270 \\
\hline $\mathrm{R} 2$ & 0.3169 & 0.3329 & 0.1839 & 0.1708 & 0.1953 & 0.2065 \\
\hline
\end{tabular}

Notes: Estimations include fixed effects at the Province-level. Standard errors are reported in brackets. Significance levels: ${ }^{\star} \mathrm{p}<0.10,{ }^{* *} \mathrm{p}<0.05,{ }^{* *} \mathrm{p}<0.01$

Table 4. Direct and Indirect Effect of Crime Rate

\begin{tabular}{lllll}
\hline Variables & Direct Effect & Indirect Effect & & \\
\hline & Coefficient & P-value & Coefficient & P-value \\
GINI & 2.261231 & 0.002 & 2.443302 & 0.022 \\
DO & 1.050067 & 0.015 & 1.113646 & 0.038 \\
UNEM & .0323418 & 0.074 & .0346635 & 0.106 \\
POV & .0193525 & 0.118 & .0207303 & 0.174 \\
EXP & -0.0001357 & 0.637 & -0.0001515 & 0.631 \\
LagPolice & -0.1684539 & 0.841 & -0.167776 & 0.867 \\
\hline
\end{tabular}

economic inequality and education level influence to crime rate at very high significance level as it shown in Table 3. In any spatial model, Gini Index are consistent and substantial to determine crime rate at $1 \%$ significant level. Similarly, senior high school dropout rate also is strongly significance to influence the crime rate at same level. Meanwhile, other variables like unemployment and poverty rate are significance in OLS model but are not significant in spatial model, indicate that those variables are only affect crime rate internally in own province, and not affecting to neighboring provinces.

Furthermore, Table 4 shows that Gini index robustly affect crime rate directly (direct effect) and indirectly (indirect effect) at significant level of $5 \%$, while unemployment rate has direct effect towards crime rate at significant level of $10 \%$. It explains that 1 unit increase in Gini index in a particular region will lead to $226 \%$ increase in crime rate in the particular region, while 1 unit increase in Gini index the whole regions (total) will lead to $224 \%$ increase in crime rate in the particular region. The similar way of interpretation is applied for percentage of senior high school dropout and open unemployment rate.

Gini index and crime rate are positively correlated spatially and strongly statistically significant. The relation between crime rate and Gini index is formulized by Becker (1968) and Kelly (2000). They stated that when a region possesses high income 
inequality, it implies that low earning population is live side by side with rich population; therefore, return of criminal actions will be relatively high. This finding is corresponding with Kelly's discovery (2000), stating that income disparity will lead to frustration for those belong to low income category; thus, triggering them to commit crime. Besides, disorganization social theory stated that criminal actions occurs because of weak social control and poverty is one factor weakening the ability of community to maintain social order. Merton Theory also stated that individuals with weak position in social structure may be frustrated with their inability to acquire successful life. This condition is exacerbated by the existence of successful people in their surroundings. At the end, the unsuccessful individuals perceive themselves to be alienated from the community and decide to commit crime instead. The perception of being alienated does not only occur because of income disparity, but also because of racial minority (Kelly, 2000).

Provinces owning high Gini index and high crime rate, such as Lampung, DKI Jakarta, West Java, DI Yogyakarta, Banten, NTB, South Kalimantan, North Sulawesi, Central Sulawesi, Gorontalo, and Papua require more treatments. In addition, regression results indicate that factors spatially significant in affecting crime occurrence, aside from Gini index, are open unemployment rate and percentage of senior high school dropout. Therefore, North Sulawesi, DKI Jakarta, Banten, West Java, Maluku and Papua also need to obtain governments' attention. The decrease in the aforementioned variables which are significantly affecting crime rate, in those regions is expected to decrease crime rate in other regions, considering that this research discovers the existence of significant spatial correlation of crime rate among provinces in Indonesia.

Percentage of senior high school dropout spatially significant in affecting inter-provincial crime rate in Indonesia. It implies that education affects individual's decision to involve in crime by increasing the individual's decision to acquire decent job in labor market (employment and wage rate) and higher market return, rendering higher opportunity cost of doing crime (Buanano and Leonida, 2009); therefore, being punished because of criminal actions incurs relatively higher cost for educated people; hence, educated people tend to avoid risk of involving in crime (risk aversion). In addition, education may affect psychologically the way individual perceive criminal actions. In other words, educated people tend to be immersed in psychological remorse of disobeying the law; hence, incurring psychological cost of doing crime (Bharadwaj, 2014). In some cases, they move to cities because cities emit immense attractiveness, both for those residing in rural areas and those residing in small towns nearby, in the form of offering wider job opportunities; thus, inducing people to migrate into and live in cities (Sjafrizal,
2012). Moreover, one of the characteristics individuals migrating to cities are those possessing low education and skill (unskilled workers).

In terms of control variable, open unemployment rate is also positively correlated spatially, and statistically significant with crime rate. High unemployment rate decreases the opportunity to earn legal income; thus, lowering the opportunity cost of being arrested while committing crime and lead to increasing crime rate. Open unemployment rate is spatially significant in affecting inter-provincial crime rate in Indonesia. People tend to search for regions offering wider job opportunities; thus, inducing inter-regional migration (Sjafrizal, 2012). Furthermore, Wiloyonoyudho, et al. (2017) indicate the lack of employment opportunities in the rural areas causes people to migrate and find work in the city. As a result, they conclude that the growth of cities due to a rapid of urbanization has caused many problems such as environment, transportation, economic, and social including crime.

However, if we are more relaxed and looking at the OLS and panel model estimation, we found that poverty rate is positively correlated spatially with crime rate. The positive correlation between poverty and crime rate has been renowned since ancient Greece era. Aristotles, a famous figure the era, stated that poverty is the parent of revolution and crime. Bharadwaj (2014) also reported that positive correlation between poverty rate and crime rate exist. Moreover, Bharadwaj (2015) added that poverty rate is the greatest push to commit thievery. The latter can be explained by relative deprivation theory mentioning that the lack of ability to acquire daily necessities forces people to commit criminal actions.

However, percentage of police is also negatively correlated spatially with crime rate; yet, statistically insignificant. Levitt (2004) mentioned that 14\% increase in number of police officers will decrease $5-6 \%$ of crime rate since police officers are the first line defense in combating criminal actions. According to Sherman in Greene (2006), the degree of commitment of police to perform their duty is more important than the number of police officers. Therefore, increasing the number of police officers will significantly affect crime rate reduction if only they perform problem-oriented policing or hotspot policing, which may be more effective in reducing crime. If police officers cannot perform their duty efficiently and have inadequate skill to handle criminal actions, the increment in number of police officers may be a futile attempt.

\section{Conclusion}

This research discovers that crime rate is spatial phenomenon. The best model to explain crime occurrence in Indonesia using 2007-2013 panel data is spatial autocorrelation model (SAC). The latter indicate the existence of spatial linkage in both independent variables and error of the model. Spatial regression 
results indicate that the Gini index and percentage of senior high school dropout are significant variables affecting crime rate in Indonesia. Our empirical model show that Gini index is the most significant factor affecting crime rate and it indicates that economic inequality may trigger crime occurrence. The Gini index depicts the conditions of income gap between the rich and the poor. Criminal actions is expected to increase as the Gini index is high. It because when the poor live in the similar area with the rich, social jealousy is inevitable; hence, triggering criminal actions. Kelly (2000), in economics of crime theory, mentioned that regions with high income inequality where the low income population live side by side with the rich ones with luxurious possessions, will trigger the low income earner to commit robbery. Their frustrated and envious feelings are transformed into motivation to involve in criminal actions. Therefore, it becomes paramount for the government to improve society's level of prosperity as a whole. In addition, reviving the fading social capital, such as mutual cooperation, tolerance, and to dispel individualistic behavior, is also substantial. The author believes that social capital is paramount to prevent frustration and jealousy occurring among the rich and the poor living together.

Furthermore, the senior high school dropout is proven to be statistically significant in affecting crime rate. Therefore, years of schooling becomes substantial factor to reduce crime rate, considering that education affects individual's decision to commit criminal actions. Human capital investment is intended to magnify the probability to obtain legal job providing adequate earnings. This finding is in tandem with Moretti (2005) mentioning that education may affect crime rate through labor market by increasing the opportunity to acquire legal income so that increase the opportunity of doing crime. Lochner (2004) added that education is considered as human capital investment to acquire future prosperity by increasing the opportunity to obtain legal occupation. Thus, improving human capital investment through education becomes a recommended policy to apply. The latter should be prioritized because education contributes indirect effect towards unemployment rate.

Observing the analysis coverage of this research, rooms for expansion and enrichment of analysis coverage remain: The data used in this research cover provincial data in Indonesia, while crime is an issue that will be better to be analyzed using urban context. The similar crime rate pattern can also be observed in Sumatera and Java. Therefore, the next research can be limited for urban context to acquire more accurate urban economic criminal actions analysis. In addition, the scope of analysis can be limited for urban area in Sumatera and Java so that spatial effect phenomenon depiction becomes clearer.

The dearth of current data makes the data for police department is limited for 3 years only, while to conduct panel regression analysis, the spatial data must be strongly balanced. Therefore, the author suggests that longer time series coverage is used, considering that augmenting police department budget as independent variable of crime rate may lead to better spatial analysis of crime rate.

\section{References}

Anselin, L., Cohen, J., Cook, D., Gorr, W., \& Tita, G. (2000). Spatial analyses of crime. Criminal justice, 4(2), 213-262 Barrett, A. (2014). Spatial Dependence in Unemployment in Great Britain, Master's Thesis. Urban, Port and Transport Economics at Erasmus University Rotterdam.

Becker, Gary. (1968). Crime and Punishment: An Economic Approach. Journal of Political Economy 76 (2): 169-217

Becsi, Z. (1999). Economics and Crime in the States. Economic Review-Federal Reserve Bank of Atlanta, 84(1), 38.

Belotti, F., and Mortari, G. H. A. P. (2013). xsmle-A Command to Estimate Spatial Panel Data Models in Stata. In Italian state users Group Meeting.

Bharadwaj, A. (2014). Is poverty the mother of crime? Empirical evidence of the impact of socioeconomic factors on crime in India. Atlantic Review of Economics, 1,1 .

Buonanno, P., and Leonida, L. (2009). Non-market effects of education on crime: Evidence from Italian regions. Economics of Education Review, 28(1), 11-17.

Bustaman, U et al., in Romzi, M. dan Bustaman, U. (2014). Penggunaan Metode Geographically Weighted Regression (GWR) untuk Analisis Data Sosial Ekonomi. BPS Jakarta.

Elhorst, P. (2014). Spatial Econometrics: From Crosssectional Data to Spatial Panels. Heidelberg, New York, Dordrecht, London: Springer.

Engelen, P.J., Lander, M.W. \& Essen, M. V. (2016). What determines crime rates?An empirical test of Integrated Economic and Sociological theories of Criminal behavior. The Social Science Journal 53 (2016), 247-262

Entorf, H., \& Sieger, P. (2015). Does the magnitude of the link between unemployment and crime depend on the crime level? A quantile regression approach. International Journal of Conflict and Violence (IJCV), 8(2), 262-283.

Glaeser, E. L., and Sacerdote, B. (1999). Why is there more crime in cities?. Journal of political economy, 107(S6), S225-S258.

Greene, J. R. (Ed.). (2006). Encyclopedia of Police Science: 2-volume set. Routledge.

Hjalmarsson, R., and Lochner, L. (2012). The impact of education on crime: international evidence. DICE Report, 10(2), 49.

Kelly, M. (2000). Inequality and crime. Review of economics and Statistics, 82(4), 530-539.

Levitt, S. D. (2004). Understanding why crime fell in the 1990s: Four factors that explain the decline and six that do not. Journal of Economic perspectives, 18(1), 163190.

Lochner, L. (2004). Education, work, and crime: A human capital approach. International Economic Review, 45(3), 811-843.

Republika (2014). http://www.republika.co.id/berita/ nasional/hukum/14/12/30/nheau7-angka-kriminalitassepanjang-2014-masih-tinggi , accessed on June 24, 2015 Moretti,(2005). Does Education Reduce Participation in 
Criminal Activities ?. Departement of Economics, UC Berkeley.

Sharp, A. M. Register, C.A. dan Grimes P.W. (2013). Econometric of Social Issues. 20th edition. New York: McGraw-Hill International Edition.

Sjafrizal. (2012). Ekonomi Wilayah dan Perkotaan. PT RajaGrafindo Persada. Jakarta.

Sujarwoto, S. (2017). Geography and communal conflict in Indonesia. Indonesian Journal of Geography, 49(1), 8996.

Sullivan, A. (2012). Urban Economics. 8th edition. McGrawHill Irwin. USA
Tobler, W. R. (1979). Cellular geography. In Philosophy in geography (pp. 379-386). Springer, Dordrecht.

Vidyatama, Y. (2012). Spatial Dichotomies in Indonesia's Regional Development. Natsem Working Paper 12/19. University of Canberra.

Wilonoyudho, S., Rijanta, R., Keban, Y. T., \& Setiawan, B. (2017). Urbanization and Regional Imbalances in Indonesia. Indonesian Journal of Geography, 49(2), 125132 